\title{
POTENTIAL IMPACT OF CLIMATE CHANGE ON AQUATIC VEGETATION OF RIVER SALACA, LATVIA
}

\author{
Laura Grīnberga and Gunta Sprinǵge \\ Institute of Biology, University of Latvia, Miera iela 3, Salaspils, LV-2169, LATVIA \\ E-mail: laura.grinberga@email.lubi.edu.lv
}

Communicated by Viesturs Melecis

\begin{abstract}
Species diversity and cover of aquatic macrophytes were investigated in the River Salaca in 2007. In total 24 different taxa were found. Schoenoplectus lacustris was the dominant species, Sagittaria sagittifolia, Nuphar lutea, Nymphaea candida, Butomus umbellatus and different Potamogeton species were frequent. Cover of macrophytes varied in the river between 10-90\%, maximum in-stream cover reached in rapidly flowing sites. Comparison of total cover of macrophytes in 1986 and 2002 surveys of several stretches was done. Causes for the changes are discussed. The increasing growth of aquatic vegetation in the River Salaca have been related to climatic factors-higher mean annual air temperatures, earlier springs and decrease in the period of ice cover in winter.
\end{abstract}

Key words: aquatic vegetation, River Salaca, climate change, Latvia.

\section{INTRODUCTION}

Aquatic macrophytes are an important component of aquatic ecosystems. Changes in community composition and in the abundance of individual species provide valuable information on how and why an ecosystem might be changing (Scott et al., 2002). Macrophytes can serve as long-term indicators of environmental conditions with high spatial resolution (Melzer, 1999).

Aquatic macrophytes are generally used for environmental monitoring and water quality assessment. Additionally, rooted aquatic plants link sediment and overlying water are therefore able to indicate conditions in both river compartments. Macrophyte response to different nutrient loads as well as anthropogenic river habitat disturbance allows them to be used as bioindicators. Aquatic plant communities respond to these impacts with changes in taxonomic composition, as well as an increase or decrease of plant abundance (Schneider and Melzer, 2003).

In the last years, the impact of climate change on freshwater ecosystems and aquatic vegetation has been investigated in different European countries (e.g. McKee and Richards, 1996; Kankaala et al., 2000; Middlekoop, 2000; Burnett et al., 2007).

The River Salaca is a little affected river in Latvia with high landscape and biological diversity. Dominance of humic podsoils is a typical feature for the River Salaca basin. Impact of agriculture on the river is insignificant, and nutrient loading has not significantly changed over the last ten years.
In the last decades, a significant increase of macrophyte growth has been observed in River Salaca. It is known that in most of the riffle river stretches overgrowing exceeds a $30 \%$ level. $^{1}$

The aim of this paper is to describe how the macrophyte composition and coverage of the River Salaca has changed and attempt to determine the underlying factors for macrophyte growth. Seven stretches in the entire length of the River Salaca were surveyed in summer 2007, and results of 1986 and 2002 mapping surveys were used for data comparison. The investigation was focused on species composition and macrophyte coverage.

\section{MATERIAL AND METHODS}

Study area. River Salaca is $95-\mathrm{km}$-long lowland river, located in the north-eastern part of Latvia (Fig. 1) in the Northern Vidzeme Biosphere Reserve. It originates in the eutrophic Lake Burtnieks (area $40 \mathrm{~km}^{2}$ ) and flows into the Gulf of Riga. The Salaca as the central watercourse combines all the impacts of the Salaca basin. In total, the river is a little-affected ecosystem, and an important salmon river. At the same time, the Salaca basin is variable in land use patterns, number of inhabitants and soil types.

The river catchment area covers $3570 \mathrm{~km}^{2}$, of which $48 \%$ are forests, and $42 \%$ are agricultural lands. The mean river

\footnotetext{
${ }^{1}$ Druvietis, I. Hydrobiological characterization of catchment of the River Salaca. Personal communication, 2002.
} 


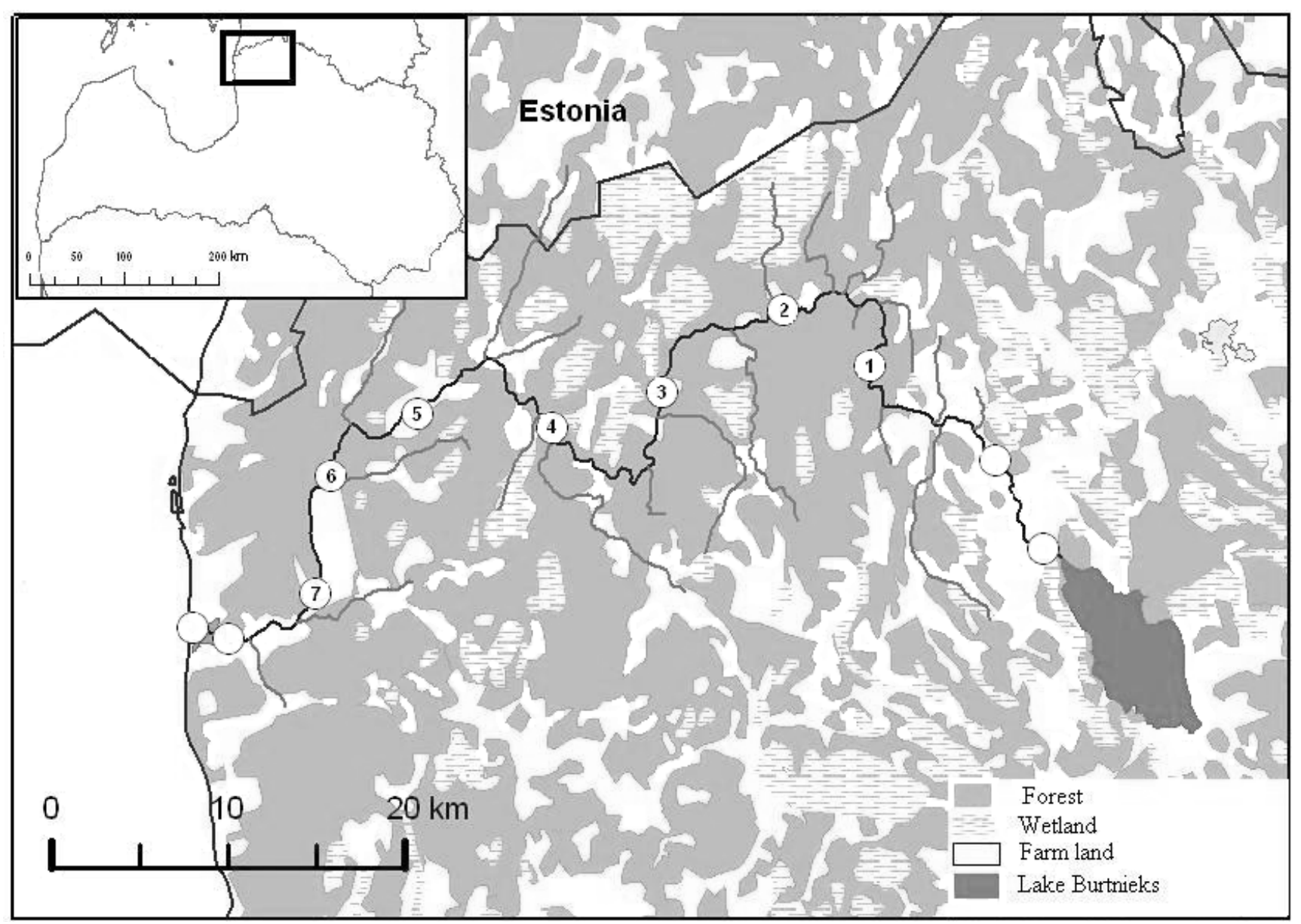

Fig. 1. Location of the River Salaca and surveyed stretches in 2007 (1, Mazsalaca - River Ramata, 2, River Ramata - River Ige, 3, River Ige - Staicele, 4, Staicele - River Puzupe, 5, River Puzupe - Sarkanas cliff, 6, Sarkanas cliff - Rostu cliff, 7, Rostu cliff - Vecsalaca).

depth is $0.7-2.7 \mathrm{~m}$, and the maximum depth is $8.0 \mathrm{~m}$. The main bottom habitat types are stony and stony-sandy.

Field sampling and data analysis. A survey of aquatic vegetation in the River Salaca was performed in the beginning of August in 2007 from the boat. The submerged, emergent and floating-leaved macrophytes were mapped in seven stretches of the river (Fig. 1). Plant cover was estimated visually as a percentage in specific river stretch lengths. For species identification plants were taken from the water using a rake with a long handle.

The length of survey stretches was 3.5-17 km (Table 1) depending on homogeneity of the river bed material.

For comparing changes in the macrophyte coverage of the River Salaca during the last 20 years, the results of surveys carried out by Andris Urtāns in 1986 (Уртанс, 1989) and $2002^{1}$ were used. The macrophyte species, their frequency and coverage were estimated in 1986. In 2002, only coverage of aquatic vegetation was estimated for each stretch of the river. In 2007, the same lengths of survey stretches and method for estimation of plant abundance, as in 1986 were used.

\footnotetext{
${ }^{1}$ Druvietis, I. Hydrobiological characterization of catchment of the River Salaca. Personal communication, 2002.
}

Table 1

LIST OF SURVEYED STRETCHES OF THE RIVER SALACA, THEIR LENGTH AND DISTANCE FROM SOURCE

\begin{tabular}{c|l|c|c}
\hline No. & \multicolumn{1}{|c|}{ Stretch* } & $\begin{array}{c}\text { Lenght } \\
(\mathrm{km})\end{array}$ & $\begin{array}{c}\text { Distance of } \\
\text { source }(\mathrm{km})\end{array}$ \\
\hline 1 & Mazsalaca - River Ramata & 14 & 11 \\
2 & River Ramata - River Ige & 9 & 25 \\
3 & River Ige - Staicele & 17 & 34 \\
4 & Staicele - River Puzupe & 12 & 51 \\
5 & River Puzupe - Sarkanas cliff & 13 & 63 \\
6 & Sarkanas cliff - Rostu cliff & 3.5 & 76 \\
7 & Rostu cliff - Vecsalaca & 11 & 79.5
\end{tabular}

*For explanation see Fig. 1.

Environmental variables of each stretch, such as bottom material content and flow characteristic were estimated visually (Table 2).

Data on air temperature of the nearest meteorological station Ainaži, river discharge and water temperature of the streamflow station Lagaste were obtained from the Latvian Environmental, Geological and Meteorological Agency for the time period 1946-2007. Long-term changes in different seasons (winter, spring, summer and autumn) of mean air temperature and water temperature were studied. 
SURVEYED ENVIRONMENTAL VARIABLES FOR EACH STRETCH OF THE RIVER SALACA

\begin{tabular}{cll}
\hline Stretches* & \multicolumn{1}{|c}{ Flow characteristic } & \multicolumn{1}{c}{ Substrate type } \\
\hline 1 & Particulary rapid & Sand, gravel, stones \\
2 & Calm flow & Sand, stones \\
3 & Calm flow & Stones, gravel, clay, muddy sand \\
4 & Calm flow & Sand, pebble, stones \\
5 & Rapid flow & Stones, gravel \\
6 & Particulary rapid & Stones, gravel, sand \\
7 & Rapid flow & Stones, gravel
\end{tabular}

*For explanation see Fig. 1.

Plant abundance was estimated according to a six-point scale established by Drude: 1 - very rare, 2 - rare, 3 - moderately abundant, 4 - common, 5 - frequent, 6 - abundant, predominant (Аноним, 1975). The amphibious plant species as well as algae, liverworts and mosses were excluded from the assessment. All macrophytes were identified to the species level except Potamogeton in particular cases because of hybridisation. The mean Ellenberg $N$-values (Ellenberg et al., 1992) were calculated for analysing the variation between stretches.

\section{RESULTS}

In total, 24 aquatic macrophyte taxa were recorded during the survey (Table 3). The most common species were Sagittaria sagittifolia, Schoenoplectus lacustris, Nuphar lutea, Nyphaea candida, Butomus umbellatus and Sparganium erectum.

The surveyed stretches were medium rich in macrophyte species (from 12 to 21 taxa per site).

The largest number of species was found in stretch No. 1, where 21 macrophyte taxa were observed, the most common submerged and emergent macrophyte species being Butomus umbellatus, Sagittaria sagittifolia, Sparganium erectum, Potamogeton pectinatus, $P$. gramineus, $P$. perfoliatus as well as floating-leaved macrophytes.

In the upper part of the stretch No. 1, Ceratophyllum demersum, Potamogeton crispus, and Spirodela polyrhiza which are often associated with eutrophic waters, were also common. In previous studies the presence of these species was linked to the impact of Lake Burtnieks, which is a source of the River Salaca. There is need for further investigations in the River Salaca above Mazsalaca for assessing impact of Lake Burtnieks and Mazsalaca.

The emergent macrophyte species Schoenoplectus lacustris, Acorus calamus, Sparganium erectum, Phragmites australis were common in the lower part of the River Salaca.

Floating-leaved macrophytes Nymphaea candida, Nuphar lutea, Hydrocharis morsus - ranae as well as species with
SPECIES FOUND IN EACH STRETCH OF THE RIVER SALACA AND THEIR RELATIVE ABUNDANCE*

\begin{tabular}{|c|c|c|c|c|c|c|c|c|}
\hline \multirow{2}{*}{ Name of species } & \multicolumn{8}{|c|}{ Stretches* } \\
\hline & 1 & 2 & 3 & 4 & 5 & 6 & 7 & $\mathrm{~s}$ \\
\hline Acorus calamus & & & & 3 & 4 & 3 & 5 & $\beta$ \\
\hline Alisma plantago-aquatica & 2 & 2 & 2 & 2 & 1 & & 2 & $\beta$ \\
\hline Butomus umbellatus & 5 & 2 & 3 & 4 & 4 & 3 & 3 & $\beta$ \\
\hline Ceratophyllum demersum & 3 & & & & & & & $\beta$ \\
\hline Elodea canadensis & 3 & 2 & 2 & 3 & 3 & & 3 & $\beta$ \\
\hline Glyceria maxima & & & & 1 & & & & - \\
\hline Hydrocharis morsus-ranae & 3 & 2 & 1 & 2 & 2 & 1 & 2 & $\beta$ \\
\hline Nuphar lutea & 4 & 4 & 3 & 4 & 4 & 4 & 3 & $\beta$ \\
\hline Nymphaea candida & 3 & 4 & 4 & 4 & 4 & 4 & 3 & $\beta$ \\
\hline Phragmites australis & 2 & 2 & 2 & 3 & 4 & 4 & 4 & - \\
\hline Polygonum amphibium & 2 & 1 & 1 & 2 & 1 & & 3 & $\beta$ \\
\hline Potamogeton crispus & 2 & & & & & & & $\beta-\alpha$ \\
\hline Potamogeton gramineus & 3 & & 2 & & & & & $\mathrm{o}-\beta$ \\
\hline Potamogeton lucens & 2 & 2 & & 3 & 4 & 2 & 2 & $\beta$ \\
\hline Potamogeton pectinatus & 5 & 3 & 3 & 3 & & & 4 & $\beta-\alpha$ \\
\hline Potamogeton perfoliatus & 3 & & 1 & 4 & 4 & 2 & 4 & $\beta$ \\
\hline Potamogeton sp. & & & 3 & 3 & 5 & 3 & 4 & - \\
\hline Sagittaria sagittifolia & 5 & 5 & 4 & 5 & 4 & 3 & 3 & $\beta$ \\
\hline Schoenoplectus lacustris & 2 & 2 & 3 & 5 & 5 & 5 & 5 & $\beta$ \\
\hline Sparganium erectum & 4 & 3 & 3 & 5 & 3 & 3 & 3 & $\beta$ \\
\hline Sparganium emersum & 3 & 1 & & 2 & & & & $o-\beta$ \\
\hline Sparganium sp. & 1 & & & & & & & - \\
\hline Spirodela polyrhiza & 4 & 1 & 2 & 2 & 1 & & 2 & $\beta$ \\
\hline Typha latifolia & 2 & & & 1 & & & 2 & $\beta$ \\
\hline
\end{tabular}

$\overline{\mathrm{s}-\text { saprobic degree }}$

*For explanation see Fig. 1. Six-point scale (Drude): 1 - very rare, 2 - rare, 3 - moderately abundant, 4 - common, 5 - frequent, 6 - abundant, predominant.

different forms of leaves Sagittaria sagittifolia and Butomus umbellatus were found in all stretches of the river.

In 2007, the macrophyte cover showed a high level of overgrowing in stretches No. 1, No. 5 and No. 7.

The percentage of macrophytic cover (mean average per stretch) was compared with the results of 1986 and 2002 surveys (Fig. 2). Comparing with 1986 survey, macrophyte cover in the river had obviously increased in 2002 and 2007. Maximum cover of macrophytes in these years exceeded $50-60 \%$ in about $40 \%$ of the surveyed lengths of the river. The most significant increase in overgrowing was observed at the stretches No. 1 and No. 4. The stretches No. 1, No. 5 and No. 7 showed coverage of 70-90\%, while no significant changes occurred in stretches No. 2 and No. 6. The highest species diversity and abundance of macrophytes were typical for fast-flowing stretches.

The use of individual saprobical degrees for macrophytes species of Latvian inland surface waters by Cimdiňš et al. (1995) indicates that aquatic plants in the Salaca characterise moderate pollution. There were no significant changes in 


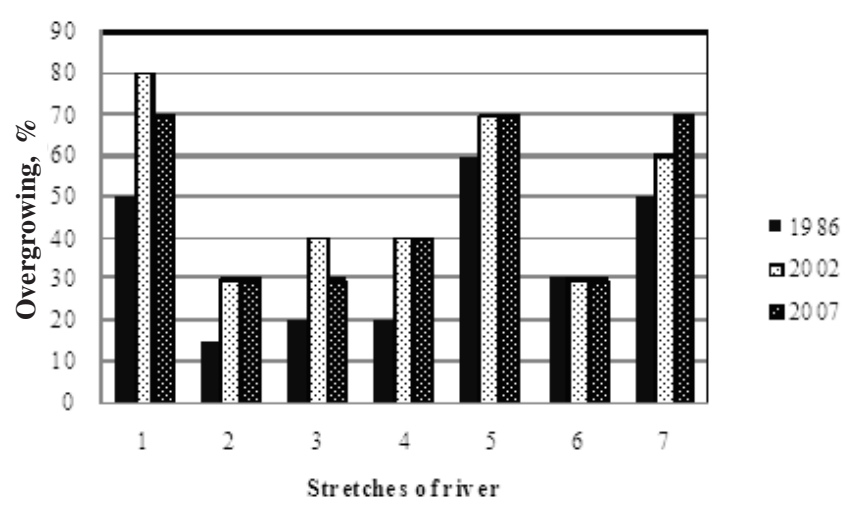

Fig. 2. Changes in the degree of overgrowing (in percent) of the River Salaca for studied stretches in 1986, 2002 and 2007, for explanation see Fig. 1.

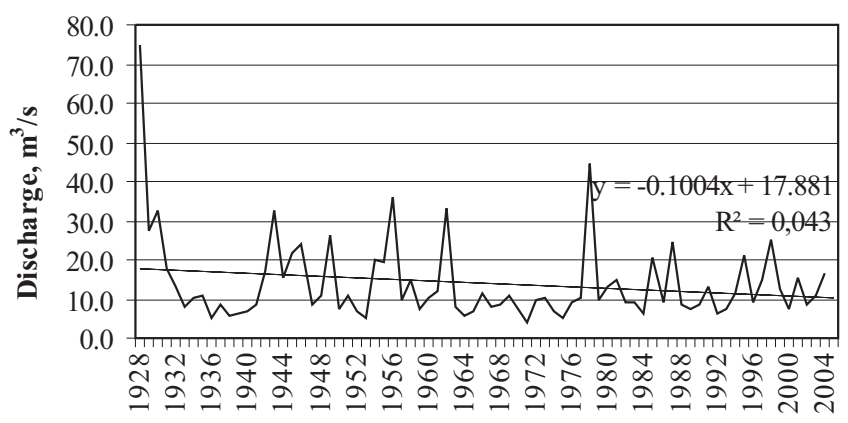

Fig. 3. Long-term changes (1927-2004) in the River Salaca discharge $(P>$ 0.05 ) in summer (June-August)

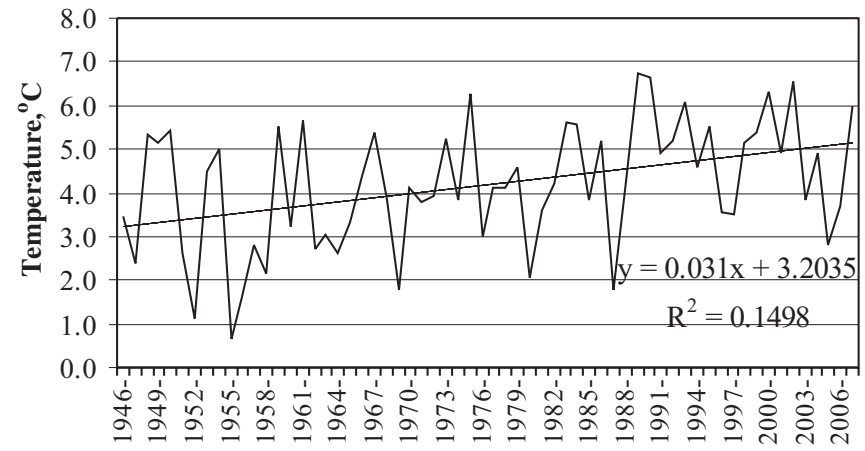

Fig. 4. Long-term changes (1946-2007) in spring (March-May) mean temperatures $(P<0.01)$ of the meteorological station Ainaži.

comparison with 1986, and species composition indicated moderate to good water quality. There were no significant differences in Ellenberg $\mathrm{N}$ values between stretches, and the resulting values varied from 5.5-6.4.

It is known that temperature is one of the most important factors influencing plant growth and is especially relevant to aquatic plants due to their close association with water and the moderating influence of water bodies on local temperatures (Burnett et al., 2007). Long-term changes in temperature can cause a decrease of water depth, velocity and subsequent changes in discharge and subsequently-aquatic plants (Hearne and Armitage, 1993).
The analysis of the long-term changes (1927-2004) of the River Salaca discharge in summer revealed that during the last century, the discharge has gradually decreased (Figure 3), while spring (March-May) mean air temperatures, according to the records of the meteorological station Ainaži, show an upward trend during the period from 1946 to 2007 (Fig. 4). Mean water temperatures varied between 11.3$15{ }^{\circ} \mathrm{C}$ in May, but in April a gradual increase was observed for the period from 1982 to 2001. Unfortunately, there is lack of data for the period from 2002 to 2005 for complete analysis.

\section{DISCUSSION}

Aquatic macrophytes are an important component of aquatic ecosystems. They offer food and shelter for many organisms and promote habitat diversity. The macrophyte abundance and species composition in streams and rivers are to a large extent controlled by chemical, physical and biotic factors. The light availability, temperature, water flow velocity, substrata type, sediment and water nutrient concentrations, inorganic carbon availability are the most important factors influencing macrophyte growth in rivers (Vereecken et al., 2006).

Observations over the last decades indicate increasing overgrowing processes in the River Salaca. At the same time in the outflow of the River Salaca a gradually decrease in nutrients $\mathrm{N}$ and $\mathrm{P}$ has occurred due to the changes in land use patterns in the catchment area of the eutrophic Lake Burtnieks, which determines the chemical composition of the upper part of the River Salaca. Further investigations are necessary for assessment of impact on macrophyte growth of euthrophic Lake Burtnieks. In the lower part of river, the water quality has improved due to the increased stream velocity and related biochemical processes. A significant difference in the main hydrochemical parameters - nutrient concentrations, $\mathrm{BOD}_{5}, \mathrm{COD}$ - has not been found for the period from 1982 to 2002 (Druvietis et al., 2007). The agricultural impact on the environment has tended to decrease. The impact of agriculture in the basin of the River Salaca has been estimated as very low and in the basin of Lake Burtnieks-as low (Jansons, 2000). Thus, we can assume that the reason for river overgrowing is not due to an increase in nutrients and intensive agriculture.

On the other hand, in the beginning of the previous century the River Salaca was important for timber rafting, which functioned as a mechanical dredge. In the 1950s, these activities were ended. Similar disturbance by ice break-up in spring is also no longer typical nowadays. At the same time better growing conditions are provided by climate warming during the previous years. Analyses of the major climate parameters show an upward trend in annual mean air temperatures (Druvietis et al., 2007), especially temperatures in spring months (Fig. 4) and water temperatures in April, decreasing ice cover period and increased length of vegetation season. It is known, that aquatic macrophyte growth and survival are clearly influenced by air temperatures (Madsen 
and Brix, 1997). Intensive macrophyte growth begins when water temperature reaches $8-10{ }^{\circ} \mathrm{C}$ (Gessner, 1955) and higher air temperatures allow the water to warm earlier. Abou-Hamdan et al. (2005) pointed out that the meteorological conditions have decisive effects: the drought in summer results in particularly low water levels, which favours overgrowing by macrophytes. In the Salaca we did not observe a statistically significant decrease in river discharge but a decreasing trend of decrease since 1927 was noticed (Fig. 3). Thus, we can hypothetically assume that this decrease may effect the growth of macrophytes in the Salaca.

The relationship of aquatic macrophytes to the substrate in which they grow is complex: they may start to grow in a certain type of substrate, but while building the structure of their plant stand, they collect material from the suspended matter load of running waters, which modifies the substrate type found under their stand over a length of time. The ability of submerged and emergent macrophytes to modify the stream environment and promote the trapping of suspended matter has been widely noted (Chambers et al., 1991; Sand-Jensen, 1998). Trapping of suspended matter is achieved through a combination of processes. Submerged and emergent plants reduce water velocities within their stands, sometimes by more than $90 \%$ (which is also noticed in the Salaca) relative to the adjacent open water (Sand-Jensen and Pedersen, 1999), and this induces sedimentation and retention of fine material and organic particles (Sand-Jensen, 1998). These deposited sediments then increase the available area for more macrophyte to take root, which in turn increases sediment deposition. Clarke and Wharten (2001) propose that abundant macrophyte growth in rivers can result in the build-up and retention of organic matter leading to elevated concentrations of total $\mathrm{N}$ and organic $\mathrm{C}$ and a high proportion of fines in the sediments. And as pointed out by Vereecken et al. (2006), despite many benefits, dense stands of macrophytes can limit the discharge capacity of lowland rivers. The increasing cover of macrophytes possibly could be also one of the factors for a decrease in the discharge capacity in the lower part of the River Salaca. Observations confirm that sedimentation processes are also obvious in the River Salaca, and re-cultivation of the more overgrown places is needed to secure optimal discharge (A. Urtāns, personal communication).

Thus, rapid macrophyte growth can affect processes in the ecosystem, which is especially important regarding spawning areas for salmonids in the River Salaca. Macrophytes create physical barriers to flow and affect also tourism possibilities and biological diversity.

Further investigations are necessary to understand changes in the ecosystem of the River Salaca. To improve spawning areas for salmons, weed clearance was conducted by the North Vidzeme Biosphere Reserve administration in separate stretches of the lower part of the river in 2006 and 2007, which will allow observing the re-establishment of vegetation. The future monitoring aims include characterising ongoing changes in vegetation structure of the river, es- pecially for those river stretches where overgrowing is expected to increase.

\section{ACKNOWLEDGEMENTS}

This study was financially supported by the European Social Fund. The author wishes to thank Andris Urtāns for the macrophyte data material of 1986 and 2002.

\section{REFERENCES}

Abou-Hamdan, H., Haury, J., Hebrard, J.P., Dandelot, S., Cazaubon, A. (2005) .Macrophytic communities inhabiting the Huveaune (South-East France), a river subject to natural and anthropic disturbances. Hydrobiologia, 551, 161-170.

Burnett, D.A., Champion, P.D., Clayton, J.S., Ogden J. (2007). A system for investigation of the temperature responses of emergent aquatic plants. Aquatic Botany, 86(2), 187-190.

Chambers, P.A., Prepas, E.E., Hamilton, H.R., Bothwell, M.L. (1991). Current velocity and its effect on aquatic macrophytes in flowing waters. Ecol. Applic., 1(3), 249-257.

Chambers, P.A., DeWreede, R.E., Irlandi, E.A., Vandermeulen, H. (1999). Management issues in aquatic macrophyte ecology: A Canadian perspective. Can. J. Bot. 77, 471-487.

Cimdiņš, P., Druvietis, I., Liepa, R., Parele, E., Urtāne, L., Urtāns, A. (1995). A Latvian catalogue of indicator species of freshwater saprobity. Proc. Latvian Acad. Sci., Section B, No. 1/2, 122-133.

Clarke, S.J., Wharton G. (2001). Sediment nutrient characteristics and aquatic macrophytes in lowland English rivers. Sci. Total Environ., 266, $103-112$.

Druvietis, I., Briede, A., Grinberga, L., Parele, E., Rodinovs, V., Springe, G. (2007). Long-term assessment of hydroecosystem of the River Salaca, North Vidzeme Biosphere Reserve, Latvia. In Climate Change in Latvia. (pp. 173-192). Riga: University of Latvia.

Ellenberg, H., Weber, H.E., Düll, R. (1992). Zeigenwerte von Pflanzen in Mitteleuropa. Scripta Geobotanica, 18, 1-258.

Georg, A., Janauer, Lanz, E., Filzmoser, P., Exler, N. (2006). Breg and Brigach, source streams of the Danube: Changes based on macrophyte surveys 1967, 1989, and 2004. Proceedings of the 36th International Conference of International Association for Danube Research, 7-8 September 2006. (pp. 86-90). Austrian Committee DanubeResearch. Vienna.

Hearne, J.W., Armitage, P.D. (1993). Implications of the annual macrophyte growth cycle on habitat in rivers. Regul. Rivers. Res. Man., 8, 313-322.

Jansons, V., Vagstad, N., Sudars, R., Deelstra, J., Dzalbe, I., Kirsteina, D. (2002). Nutrient losses from point and diffuse agricultural sources in Latvia. Landbauforschnung Volkenrode, 1(52), 9-17.

Kankaala, P., Ojala, A., Tulonen, T., Haapamaki, J., Arvola, L. (2000). Response of littoral vegetation on climate warming in the boreal zone: An experimental simulation. Aquatic Ecol., 34, 433-444.

Lacoul, P., Freedman, B. (2006). Environmental influences on aquatic plants in freshwater ecosystems. Environ.Rev./Dossiers Environ. 14(2), 89-136.

Madsen, T.V., Brix, H. (1997). Growth, photosynthesis and acclimation by two submerged macrophytes in relation to temperature. Oecologia. 110, 320-327.

McKee, J., Richards, A.J. (1996). Variation in seed production and germinability in common reed (Phragmites australis) in Britain and France with respect to climate. New Phytol. 133, 233-243.

Melzer, A. (1999). Aquatic macrophytes as tools for lake management. Hydrobiologia, 395/396, 181-190.

Middlekoop, H. (2000). The impact of climate change on the River Rhine and the implications for water management in the Netherlands. Lelystad: Lelystad: RIZA (Institute for Inland Water Management and Waste Water Treatment). $156 \mathrm{pp}$. 
Sand-Jensen, K. (1998). Influence of submerged macrophytes on sediment composition and near bed flow in lowland streams. Freshwater Biol., 39(4), 663-679.

Sand-Jensen, K., Pedersen, O. (1999). Velocity gradients and turbulence around macrophyte stands in streems. Freshwater Biol., 42(2), 315-328.

Sarbu, A., Janauer, G., Exler, N., Filzmoser, P. (2006). The aquatic vegetation of large Danube river branches in Romania. In Proceedings of the 36th International Conference of IAD, Austrian Committee DanubeResearch (pp. 101-106). Vienna.

Schneider, S., Melzer, A. (2003). The trophic index of macrophytes (TIM) - a new tool for indicating the trophic state of running waters. Int. Rev. Hydrobiol., 88, 49-67.
Scott, W.A., Adamson, J.K., Rollinson, J., Parr, T. W. (2002). Monitoring of aquatic macrophytes for detection of long-term change in river systems. Environ. Monitor. Assess., 73, 131-153.

Vereecken, H., Baetens, J., Viaene, P., Mostaert, F., Meire, P. (2006). Ecological management of aquatic plants: Effects in lowland streams. Hydrobiologia, 570, 205-210.

Аноним (1975). Методика изучения биогеоценозов внутренних водоемов [Methods of investigation of inland waters]. Москва: Наука, c. $17-132$.

Уртанс, А.В. (1989). Структура и распределение высщей водной растителности в р. Салаца [Structure and distribution of aquatic plants in the River Salaca]. В книге: Биоценотическая структура мальх рек. Бассеин реки Салаца. Рига, Зинатне, с. 163-182 (in Russian).

Received 21 January 2008

\section{KLIMATA IZMAIN̦U POTENCIĀLĀ IETEKME UZ AUGSTĀKO ŪDENSAUGU VEGETĀCIJU SALACĀ}

Augstāko ūdensaugu sugu sastopamība un kopējais aizaugums ar ūdensaugiem Salacā pêtīts 2007. gada vasarā. Konstatēti 26 augu taksoni. Sugu sastāvā dominē ezera lielmeldrs Schoenoplectus lacustris, bultene Sagittaria sagittifolia, dzeltenā lēpe Nuphar lutea, ūdensroze Nymphaea candida, puķumeldrs Butomus umbellatus. Plaši izplatītas arī dažādu sugu glīvenes Potamogeton sp. Kopējais aizaugums ar ūdensaugiem Salacā ir mozaīkveida, augstākā aizauguma pakāpe konstatēta upes krāčainajos posmos, kur tā sasniedz 70-90\% no upes virsmas. Balstoties uz agrākajiem 1986. un 2002. g. pētījumu rezultātiem, salīdzinātas aizauguma pakāpes izmaiṇas vairākos Salacas posmos un apskatīiti iespējamie izmaiņu cēloṇi. Strauji pieaugošais upes aizaugums Salacā ir potenciāli saistîts ar klimatiskajiem faktoriem - augstākām gaisa temperatūrām pavasara mēnešos, agrāku pavasara iestāšanos un ledus segas biezuma samazināšanos, kā arī ar mazāku dienu skaitu, kad upi klāj ledus. 